\title{
ARABIC LEARNING MATERIAL OF HIGHER EDUCATION MUSLIM COMMUNITY NORTH SULAWESI
}

\author{
Ismail Suardi Wekke* \& Oman Karya Syuhada \\ *State Islamic College (STAIN) of Sorong \\ Email: iswekke@gmail.com \\ **State Islamic University (UIN) of Sunan Gunung Djati, Bandung \\ Email: okaryasyuhada@gmail.com
}

Paper Presented in

The International Conference Arabic Language Education and Literature and Islamic Values between Expectation and Realization

Bandung, 11-12 November 2016

\begin{abstract}
Arabic has a special characters and positions compare to bahasa Indonesia as the mother tongue of students. These conditions are prospect to create joyful learning and teaching. Therefore, through the teaching and learning it is the opportunity to accelerate the process of understanding source language. This research was conducted in higher education of north Sulawesi in Manado. Non-participant observation and in-depth interview were conducted to collect data. Four months of research was studied from May to September of 2016. There was three circles of focus group discussion in validating data for triangulation. This article shows that the learning material consists of two categories language competency and religious teaching. This study illustrate that learning material was integrated to teaching of Islam. Religious material used to developed interactive substantial discussion and the medium of conversation is the Arabic. Additional activities and class hour was programed to enhance student chance to learn and practice outside formal classroom. There were some instructors were provided to maintain student training for couple weeks. This research discusses that in the field of Arabic language learning emphasize constructing learning opportunity environments, it is important which contents are included and it is also students' great interest how these contents are presented. Lecturers and instructors tried to provide instructional explanations. Furthermore, they communicate and demonstrate prior knowledge and student motivation in determining learning outcomes. The learning provide student opportunity to acquire conceptual knowledge and language competency. The article concludes by considering how embodied language material learning to religious content is the way to speed up two subject in one teaching for curriculum enhancement.
\end{abstract}

Keywords: learning material, instruction, content, discussion, activities.

\section{INTRODUCTION}

Arabic lesson in colleges is aimed to give the students basic skills to develop in their life. As persons, members of society and citizens of the world, their educational level will give them capability to live the life. Thus, learning materials provided should in line with their life itself. When a learning material is far from real life, it even keeps the learning 
context at the distance, that is, the life. This chapter explains Arabic learning materials, characteristics, Arab culture and Arabic language position as a language of religion, including variations of Arabic language which is classified into official (formal) and non-formal languages. This becomes a part of main discussion in each Arabic learning process.

Language is an element related to each other in an integrated system. Taha-Thomure suggested that language is a system of sounds consisting of arbitrary (voluntary) symbol used by one or groups (Taha-Thomure, 2008). Mahmoud explained that language is a system formulated by symbols attempted and changeable to express personal objectives and used for communication among individuals (Mahmoud, 2013). Meanwhile, Dean defined a language as psychological, social, cultural but non-biological symptoms that can be attempted, consisting of symbols of sounds containing meanings so that it can be used for communication (Dean, 2014). In the third statement, though using different sentence, it is agreed that a language is not a simple system. There is relationship between some aspects which makes them to be meaningful symbols. Language has become means of expression and communication among people or part of communication activity.

\section{ARABIC LEARNING MATERIAL ANALYSIS}

Arabic learning material taught should be adjusted to learners' conditions. Therefore, the first step that should be done is to know what learning stages have been experienced by the learners. Setting materials to be learnt will create a new experience. Not repetitions in some particular levels which will create boredom. A material should not far from comprehension which has been studied in previous level. When this happens, this will create gaps separating learning experiences which are being occupied.

Learning foreign languages in Islamic school will be in relation with running formal learning programs. Curriculum requirements have been set to be parts of education 
administration (Wekke, 2012; Wekke, 2013). Meanwhile, there are other subjects. So that, to run learning and teaching process, it is necessary to analysis formerly which material will be delivered (Wekke, 2015a). So, with limited time, the existing targets can be achieved by finishing learning program. This is also in relation with the principle of that not all things should be taught in the class. Some materials even can be passed by giving the students chances to do self-study. It can also just by structured practices to help the learning process taking place in the class. Therefore, time limitation which has been set is not a problem.

Materials that need attention in Arabic learning are divided into three parts are phonology, morphology and syntax. The first part is phonology. This part becomes a basis of mastering both listening and speaking skills. Speaking is the first language skills. So that writing is a skill taught in the following level. Speaking is accentuating sound aspects and explaining right pronunciation and all of its aspects that have not been used in writing skill. In line with the nature of language learning process, speaking is earlier than writing. As a child who wants to master writing skill in the next stage, not in the initial stage of language learning. For the level of Islamic elementary school, it will be functioned when language learning process is started by introducing sounds of letters and pronouncing them with appropriate makhrajul huruf (sound sources of letters). This is also got by the students in other places as they studied reciting Koran. However, repetition may give them perfect skills and there is mutual supportiveness between Arabic learning with the ability of reciting Koran.

Beginners need times to practice, tenacity and continuous program. It is not easy to find the equivalents of Hijaiyyah letters in Bahasa Indonesia. It will be difficulties in pronouncing phonemes of Arabic language. As adaptation of Arabic words which are taken as vocabularies of Bahasa Indonesia, it needs diversion so that the words can be pronounced by Indonesian people, like from the word diwan to dewan, waqt to waktu, qadr to kadar and majlis to majelis. Contrarily, there are phonemes in Bahasa Indonesia which have no 
equivalents in Arabic language. Letters in Bahasa Indonesia like $\mathrm{p}, \mathrm{g}$ and ng will be different when pronounced by Arabic speaker.

The second part is morphology. Adopting Arabic language to Bahasa Indonesia becomes a chance to learn Arabic language in a better manner. Explaining morphology may use, among others, explanation about adopted and borrowed vocabulary. However, there are two things changing from such adoption are shift of meaning and change of pronunciation. With regard to shift of meaning, original meaning in Arabic language is not similar with it when used in Bahasa Indonesia. Such as the word diwan which means office in Arabic language, but means dewan in Bahasa Indonesia. Both of words have different meaning according to the use of respective speakers. The next one is the change of pronunciation. Khabr in Arabic language is adopted to be kabar in Bahasa Indonesia. Like mumkin in Arabic language to be mungkin in Bahasa Indonesia.

The aspect of sharaf (morphology) particularly in tashrif (conjugation) is not found in Bahasa Indonesia. So that the learning pattern with regard to the tashrif materials is a chance to enrich vocabularies. The students are guided to understand tashrif patterns and then apply them in formulas which are appropriate to the initial patterns, in addition to continuous practices which are not just in memorizing but more on the word formation, including formatting words in singular form to plural from. When this matter has been mastered, it will be better for the students to continue the lesson to the next parts. Without mastering plural word formation, they will face difficulties to learn al-'adad (counting). If they have not mastered $f i$ 'il (verbs) formation, they will not be able to place verbs in complete sentences.

The third part is syntax. A perfect concept of sentence is supported by grammatical skill $(n a h w u)$. This can be started by introducing the words existence. Each word in a sentence will be given a sign of vowel as its function. There must be correspondence between every word with others to form a sentence. The first correspondence is about mudzakkar and 
mu'annats. Although a sentence is not completed by signs of vowel, it will be read as it is completed by the signs. This is because of each word existing in a sentence has its respective function which labels itself with suffixes $a, i$ or $u$ since in term of signs changing, there are just on the last letters which should be changed. Whereas the other letters will not change though has different word function. This includes changes caused by the subject. Nevertheless, when a word function is changed by the subject, the change is not only about the letter form but also about addition that is according to the effects caused by the subject.

Perhaps there are arbitrary elements in other languages, but there is nothing like that Arabic language. The existence of Koran is being a patron of Arabic development after the completion of the revelation. There is a correspondence between the use of language and socio-cultural factor of the society who form it. Moreover, one of typical characteristic of Koran is on its linguistic excellence. There is the element of regularity in meanings. Arabic language is supported by a tool which has been established, that is, sharaf. Using this pattern, each formatted word does not present suddenly. So even though there is an element of arbitrariness, then it is very minimal.

\section{CHARACTERISTICS OF ARABIC LANGUAGE}

Arabic language writing is started from the right side to the left one. Starting Arabic learning requires introduction to hijaiyyah letters first. It is continued by recognizing each letter and then arranging them if they are in one word. There are distinctive forms of letters in Arabic language. There is no difference of capital and non-capital letters in Arabic language. Interactions with other languages in academics traditions influence Arabic language on the use of commas, colons, quotation marks and other marks in sentences (Wekke, 2014). These are not characteristics of Arabic language since the beginning. Arabic letters will change when take place in different places. The letter $b a$ will have different shapes when it takes 
place in the initial, center, or final parts of a word. These changes of the letter forms become necessary to master in writing skill.

Since the beginning, Arabic language didn't have harakat (signs of vowels) on letters. However, when foreign people in the world which were not using Arabic language were starting to embrace Islam, they found difficulties to read Koran. When one is reading Koran but not in accordance with the signs of vowels as they should be, it will lead to shift of meanings and even to deviation from what the verse means. Recognizing difficulties like this, harakat (signs of vowels) were started to be given to help in reading Koran. However, books of fiqh and religious lesson still not be given harakat. It is because, solely, that Arabic language did not have harokat since the beginning. So did the condition of the books which were not read by people who did not want to go deep in the religious lessons. So that, just people who understand and have Arabic reading skill will touch them.

Arabic language, typically, has concept of I'rab which none of other languages has. Literally, it means explaining or describing. Of the term, I'rab means the change of harakat of each word due to its position in the sentence. The change of word position is marked by the change of harakat. The change of harakat leads to the change of meaning. I'rab describes correlation of words and varied structures of sentences. Deviation of harakat in a word will change its meaning. Thus, I'rab is used to describe words. I'rab determines meanings. Deviation of I'rab may lead to a great deviation of meaning. ${ }^{1}$ None of other languages has these characteristics. They have no term of I'rab. They just rely on linguistic cues and combination of words or correlation between phrases and clauses.

\footnotetext{
${ }^{1}$ For instance, a litterateur listened to Koran recitation that was from al-Taubah verse 3 that is written innallaha bari'um minal musyrikina wa rasuluhu. But the reciter read it by kasrah on the last part of the verse innallaha bari'um minal musyrikina wa rasulihi. The litterateur commented, 'No, it is impossible that Allah disassociates Himself from His messenger'. The explanation of this comment is that if lam of that word is read by kasrah, it means Allah disassociates Himself from mushrikeen and His messenger. Meanwhile, if it is read by dhammah, it means that Allah disassociates Himself from musyrikeen. This is an explanation of why Arabic language is related to I'rab.
} 
A fact that is widely experienced by all corners of the world is that Koran is read in Arabic language. Even if found in a language other than Arabic, then it's just a translation course. Although it is difficult to find Muslim's attention seriously to Arabic language, a theological aspect to read Koran in Arabic language is still required. In area of Southeast, East, and South Asia, Arabic language is, sociologically, not spoken (Eldin, 2014). NonArabic language speakers are dominantly embracing Islam there. It term of number of Islam embracers, Indonesia takes the higher number of them than other countries. This shows that Arabic language has lingual element that is unchangeable when being translated into other languages. With this typical characteristic, Koran cannot be translated carelessly. As well as it is impossible to implement tajwid in relation to the translation, if any. The beautiful Arabic language and its attractiveness become the most important part of Arabic language and, at the same time, a language of Koran.

There is correlation between language and substance of revelation. In this position, translation of Koran is never called as Koran. Koranic verse like in the Surah of Yusuf (12):2 which explains the existence of Koran in Arabic language. Arabic letters that is called calligraphy encourages creativity of shaping Koranic letters in a variety of styles. These calligraphies then fulfill masjids and buildings used for religious purposes including the Ka'bah and houses of scholars. So does mass production of calligraphies placed on wall calendars and paintings. Night markets, sometimes, provide artists offering services to write names in Arabic calligraphy. Although does not occupy sacral position, Arabic letters paintings are being inseparable parts from masjids. Masjids' walls are decorated by calligraphies containing famous selected verses using striking colors though some of them are very difficult to read. They are solely complementary decoration for masjid's architectures. Whereas Koran is always written using standardized khat naskhi. This is because of that Koran should be read by the people including those who do not understand variations of 
calligraphies that are difficult to read. This avoids writing Koran using styles other than naskhi style.

The change of letter shape in words according to its position gives chances to develop khat so that there are styles and variations of khat are continuously developed from its initial style called khat naskhi that is standards of Koran writing. It also gives chances to develop Arabic language writing as contemporary development. Therefore, there is branch of Koranic khat competition in Musabaqah Tilawatil Quran (MTQ) as arena for artists who are not merely mastering standardized khat but also who have been developed it which art approaches. Arabic learning also needs this term in the form of contemporary as an attempt to develop the patent khat. So that the students writing skill is not limited to the introduction to the standardized khat.

Al-Rajhi, Barlett, \& Altman described number of characteristics of Arabic language (Al-Rajhi, Bartlett, \& Altman, 2013). Some of them are reviewed philosophically. This is the typical characteristics of Arabic language which have similarity to other languages. At the same time, they themselves make it different from other languages in the world. Correlation between words in Arabic language is not formed based on a correlation mediated by means. Subject-verb relationship is solely mentalistic relationship. No word is needed to be a means to show the relationship. Structures of Arabic language are formed from sequence-based ideas, not based on time or place. In this viewpoint, something would not be realized in the real world as long as people do not think and describe it. Thus, carefulness is necessary to understand sentences, mainly, the relationship between good subjects and predicates, both with long sentences containing some clauses or no interludes at all.

Furthermore, in Arabic language, each word is always inherent with the individuals. The individual shapes are always appearing as pronouns as natural structure and not as additional thing. The pattern of verb formation is always based on the subject so that by see it 
once, we can find who is the doer of the verb (Roslan Mohd Nor \& Malim, 2014). Like the word qara'a, this kind of verb is only used for huwa. Whether huwa is mentioned literally or not, the subject of qara'a must huwa. There are 16 pronouns which affect the formation of verbs. Each verb is subjecting to the pronoun it shows.

Furthermore, characteristics of Arabic language are also shown in the form of rhetoric panel. In a classification initiated by Mario Pei, Semitic model is marked by the use of excessive parallelism. This model is found in languages of Asian countries. Parallelism of Arabic language is seen in the use of words as means of connection between words, phrases, clauses, sentences and paragraphs. There are distinctive difficulties to determine the last of sentence due to the abundance of the texts. This characteristic is usually easy to find in classic books or popularly called yellow books. In a simple manner, the word waw can be translated as a comma, unless when it is a detail as a part of sentence. So that it is possible that the equivalent words in the other languages are in the form of punctuation marks, not always in the form of words.

\section{ARABIC LANGUAGE AS RELIGIOUS LANGUAGE}

In religious communication, Arabic language is the main and the only language. Shalat is can be performed only using Arabic language. So is the Koran, no other language is used to read it. The history of Koran compilation into one mushaf was using the dialect of quraish as basic standards of its writing. However, it was done without denying other dialects can be used to read the Koran. It even developed to a unit of branch of science named qira'at alQuran. In Islamic tradition, there are qira'at shab'ah (the seven ways to read the Koran). All of them are still be implemented and taken as standards to read the Koran.

The elegance of the Koran in narration is found as combination of elements, vocabularies, sentences and verses. The presence of the Koran then gives chance to Muslim 
to review how to go deep into the Koran by linguistic approaches. When there are linguistic analyses in Europe and America emerging from the development of literary works, Islamic world is developing language skills, mainly Arabic language, as part of attempts to understand Islamic teachings. This spirit has been spread not solely in the context of Arab region. Whoever embraces Islam, regardless of his/her race and language, he/she will take the Koran as life guidance. When it occurs, going deep into Arabic language is the first and main need. Thus, Islamic scholars are vying to produce works to help Muslim to understand the Koran comprehensively.

\section{ARABIC LANGUAGE AND CULTURE}

People, culture and language are inseparable. No one can understand a language without knowing its culture and vice versa, no one can understand a culture without understanding its language. In relation with the discourse, some argumentations of experts taken as basis to respond hypothesis are divided into three are, firstly, a view stating that language structure determines ways used by the speakers in doing their daily activities. Secondly, a view that states that the culture of human group can be seen from language they use. Thirdly, a view suggesting that there is only a slight correlation or even there is no correlation at all between language and culture. Generally, there are pros and cons, particularly in the first and the third views. The second one was emerging to compromise the two views by giving explanation as a middle way of the two existing views.

Language can be in the forms of discourse and text. These two forms are sometimes considered the same. This started from a view which stated that a text was a formulation of sentences interrelated with each other which not only in the form of grammatical units but also forms meaning units. In providing views on this discourse, it is suggested that a discourse is the most complete unity of language in a grammatical hierarchy as the higher and 
the greater unit formed in a complete composition. Linguistic study cannot be performed partially. It should be done integrally. Language is always containing social norms living and integrated with human speaking. Nothing is taken from text. Language is in correlation with broader life aspects. Thus, language is no longer just a matter of linguistics but has reached a broader review and even has reached anthropological and sociological reviews. The change of language reviews involves other disciplines. Reviewing language requires the engagement of the element of society where the language is growing up continuously.

This shows that communication is related to textual context and, at the same time, is on non-textual context. Therefore, it is understandable that a discourse is always in correlation with factors out of language. Contextual atmosphere leading to language events is also playing role. A discourse still uses language as medium. But things resulted by the discourse is beyond the matter of language. No longer in linguistic borders, but has reached things beyond the scope of language. Even sometimes the vociferation of discussion beyond linguistic parts then becomes part which gets special attention. In another word, there is more attention to that part than focusing on the existing discourse (Sidani \& Showail, 2013).

The presence of the Koran is being trigger of Arabic language development. Before the revelation of the Koran, Arabic language had been in a literature development which could not be considered as in low level. Arab culture putting language as the main element in their life made giving high level of appreciations upon poems, speeches and minstrelsies as tradition. Even, periodically, there were markets particularly established to appreciate literary works. The acceptance of the Koran became a motivation to perform an activity to go deep into styles of languages starting from the Koran. In relation to styles of language, Ibnu Qutaibah (w. $267 \mathrm{AH}$ ) stated that language style is fully dependent on situations and conditions, meaning domains and personal capability to arrange speech. The fully dependence of language style on many variables encourages Arabic language to develop 
continuously. In line with the development of Islam abroad out of the Arabian Peninsula, Islamic people coming from non-Arab tribes then followed to learn Arabic language. They gave their contribution to the language development.

The shift of the speaking people leads to the change of language characteristics. It is in line with the demand of modern times which provides a place for the recognition of individual works including literary works, no longer seeing communal form as single aspect. It also includes how the context accompanies the use of language uniquely (Wekke, 2015b). The difference of individual and communal context makes language speech spoken is also different. So does the difference of social environments, it also places on situations which never be the same.

The formation of vocabularies in a language, including in Arabic language, is determined by the strength of the language itself and its interaction with culture in where it grows up. Arabic vocabularies are added in line with concepts existing within its culture and the broader scope of Arabic language that is developing abroad, not only in the Arabian Peninsula. Even, in line with the spread of Islam out to other continents, Arabic language became learnt as lingua franca. As well as when the Islamic power was accepted and developed, Arabic language became part of such development. The rich vocabulary of Arabic language is determined by gradation of meanings with different vocabulary to determine standards of things.

To draw the word 'thirst', it is just not by one word. The word 'al-athasy' means thirsty caused by the desire to drink. When the desire is growing up, Arabic language uses 'alzhama'. The upper level is 'as-shada', then 'al-awam'. Finally, the word 'al-hiyam' is used to express kind of 'thirst' which leads to the death. For instance, Bahasa Indonesia needs other words to express different degrees. The use of words lebih, amat, sangat, terlalu, is being complementary of one word or they can be also used for other words. Meanwhile 
Arabic language just uses one word to show the different degrees. The existence of vocabulary, like that, actually is only a means. However, it should be noted that the culture is the factor forming the existence of vocabulary which brings to the richness in expressions. The rich of word formats in Arabic language is not the same with other languages. Other languages have richness in their own environments. Like Bahasa Indonesia which is also rich in expressing the word 'beras' (rice) as Indonesian culture is covered by the world of rice and its derivative products.

So does linguistic part which forms the richness in vocabulary. In Arabic language, there are four elements playing role in the formation of vocabulary are taraduf, isytirak, tadhadh and isytiqaq. The first is taraduf (synonym). With this pattern, there are various words in one meaning. Like the word al-saef (sword) which has more than 1000 names and al-asad (lion) which has 500 named. As well as al-tsu'ban (snake) has 200 names, al- 'asal (honey) has 80 names. Secondly, various meanings which still refer to one word or one word referring to many meanings. It is called isytirak (homonym). Still in the explanation of Ya'qub, al-khal may give birth to word meanings up to 10 words, while al-bint may form up to 30 words. These are examples of how words in Arabic language have homonyms that were formed by its wide culture, not limited solely in Arabian Peninsula.

The third is tadhahd (antithetical polysemy). Ba'balaki mentioned this term as antithetical polysemy, that is, a word shows specific meaning and its antonym, simultaneously. It is possible that tadhadh is part of isytirak. However, in tadhadh, a word has two opposing meanings. For instance, al'basl means halal or haram, al-jun means alabyadh (white) or al-aswad (black). The last is isytiqaq, that is, taking a word from the other words by maintaining the conformity of meaning. There is suitability of meanings formed based on such change of meanings. Isytiqaq is divided into the following four categories. Isytiqaq shaghir means tashrif-based change which starts from fi'il madhiy to ism maf'ul. 
There is similarity of meaning of the initial word. It will change according to the word formation. The next is isytiqaq kabir where there are same letters with different arrangement, but the meanings are not different, such as the words hamada and madaha. Both of them have similar letters in different arrangement but have the same meanings. The third is isytiqaq akbar or ibdal where one of two words has adjacent sounds of letters or two different letters but have the same makhraj. Other characteristics have the same properties, so that they have similarity. Like the words na'aqa and nahaqa. The letter 'ain and ' $h a$ are different but have the same sound source. The former word means shouting, while the latter means producing a voice. The words dhanna and danna have difference in the letters of dha and $d a$ which are exiting from the same source. The former means droning (human) and the latter means sounding (object). There are the letters sha and sin in the words al-shirath and al-sirath. Both of them have the same meaning, that is, way. Finally, sentences derivation, that is, a combination of two or more words which form a new word reflecting abbreviation. The relationship formed solely is philosophical, such as word amma which stands for 'an wa ma, basmalah is the designation for bismillah al-rahman al-rahim.

\section{CONCLUSION}

System becomes a key of a language. At least, a language was formed from sound and meaning systems. Just using particular sound could form particular meaning. Words combinations, subsequently, were used as symbols in interactions which are mutually understandable. There were also agreements among the users on meanings that are formed arbitrarily. Languages then changed accordingly to respective conditions influenced by multidimensional factors out of linguistic factors. These differences may be a chance to teach Arabic language materials by starting with the similarities or the differences. It can be done in the level of Islamic senior high school. Learning process using materials of similarities and differences is not taught in a complicated and complex manner. But as an initial concept to let 
the students use this tool when finding any similarity and difference during their Arabic learning. Learning vocabularies will be more productive if they place vocabularies in complete sentences. So that, memorizing vocabularies is no longer by memorizing individual words but by placing them in contextual forms. This will make them understand the shift of meanings by comparing them in the sentences.

\section{REFERENCE}

Al-Rajhi, I., Bartlett, D., \& Altman, Y. (2013). Research note: the development of an Arabic cross-cultural adjustment scale. Cross Cultural Management: An International Journal, 20(3), 449-463.

Dean, J. (2014). Muslim values and market value: a sociological perspective. Journal of Islamic Marketing, 5(November 2012), 20-32.

Eldin, A. A. T. S. (2014). A Cognitive Metaphorical Analysis of Selected Verses in the Glorius Qu'ran. International Journal of Applied Linguistics \& English Literature, 4(2).

Mahmoud, A. (2013). A linguistic perspective of the effect of English on MSA: Manifestations and ramifications. Journal of King Saud University - Languages and Translation, 25(1), 35-43.

Roslan Mohd Nor, M., \& Malim, M. (2014). Revisiting Islamic education: the case of Indonesia. Journal for Multicultural Education, 8(4), 261-276.

Sidani, Y., \& Showail, S. (2013). Religious discourse and organizational change. Journal of Organizational Change Management, 26(6), 931-947.

Taha-Thomure, H. (2008). The status of Arabic language teaching today. Education, Business and Society: Contemporary Middle Eastern Issues, 1(3), 186-192.

Wekke, I. S. (2012). Pembelajaran dan identitas muslim minoritas (upaya penguatan lembaga pendidikan Islam Papua Barat). Jurnal Ilmu Pendidikan Al-Rabwah, VI(2), 75-94.

Wekke, I. S. (2013). Pengembangan kurikulum pendidikan agama Islam muslim minoritas: pesantren Nurul Yaqin Papua Barat. Jurnal Pendidikan dan Pembelajaran Dasar Madrasah, 5(2), 91-116.

Wekke, I. S. (2014). Tradisi pesantren dalam konstruksi kurikulum bahasa Arab di lembaga pendidikan minoritas muslim Papua Barat. Jurnal Sosial \& Budaya Keislaman Karsa, Vol. 22(1), 20-38.

Wekke, I. S. (2015a). Arabic teaching and learning: A model from Indonesian muslim minority. Procedia - Social and Behavioral Sciences, 191, 286-290.

Wekke, I. S. (2015b). Antara Tradisionalisme dan Kemodernan : Pembelajaran Bahasa Arab di Minoritas Muslim Papua Barat. Jurnal Peradaban Islam Tsaqafah, Vol. 11(2), 313332 . 